Debbie De Girolamo - Revised Submission for the IJCP

August 30, 2019

\title{
The Conflation of Morality and 'the Fair and Just Solution' in the Determination of Restitution Claims involving Nazi-Looted Art: An unsatisfactory premise in need of change
}

We reclaimed the restitution items that amounted to much more than their monetary value...We reclaimed the legacy of Marcus Heinemann...We reclaimed a painful and tragic past... We reclaimed an enormous family...We reclaimed the many contributions of the [Heinemann] descendants...Finally, we reclaimed our standing in Luneberg, once the beloved home of our family.

Dr Becki Cohn-Vargas, Descendant of Marcus Heinemann ${ }^{1}$

The most convenient for me would be to give it back. But this is importantly a question of justice and ethics and the consequences for other public museums if we cave in. ${ }^{2}$ Lars Nittve, Director of Stockholm's Moderna Museet

Throughout the literature on the restitution of Nazi-era looted art, much is made about moral obligations to return the cultural property to claimants who seek to establish ownership to an object not in their possession but who are stymied by onerous legal frameworks. ${ }^{3}$ Traditional dispute resolution processes operate within legal norms and rules which anchor the claims of parties. Moral arguments and positions seem to have become the way to avoid legal rules to achieve fair and just solutions to these claims. It is often the recognition of a moral obligation or moral entitlement which overcomes legal barriers and leads to a consensual resolution.

\footnotetext{
${ }^{1}$ Dr Becki Cohn-Vargas, "Almost Lost: The Heinemann Legacy" at <http://beckicohnvargas.com/theheinemann-legacy>

${ }^{2}$ Lars Nittve, Director of Stockholm's Moderna Museet quoted by Art Market Monitor in Marion Maneker, "Are the Lawyers Ruining Restitution? January 19, 2009 in which he is referring to the Deutsch claim against Moderna Museet for restitution of a painting by Emil Nolde; see at < http://www.artmarketmonitor.com/2009/01/19/are-the-lawyers-ruining-restitution/> ${ }^{3}$ Restitution, for purposes of this article, is used in the remedial sense of the return of the disputed object to a claimant. For a broader symbolic definition of restitution in the context of Nazi looted art claims, see O'Donnell 2011. Further, ownership refers to a legal right to the object as determined by relevant state laws; see Renold 2015 for his discussion of ownership. Also, the terms 'cultural property' and 'art' are used interchangeably in this article, both referring broadly and generally to 'cultural objects' in line with the language used by the UK Spoliation Advisory Panel; see Terms of Reference, section 1 at <www.gov.uk/government/groups/spoliation-advisory-panel>
} 
Debbie De Girolamo - Revised Submission for the IJCP

August 30, 2019

As will be seen in this article, achieving fair and just solutions is the objective that has been established for disputes relating to the restitution of Nazi looted art. Morality is frequently used as a basis for achieving a fair and just solution of such disputes: it is not unusual to see bantered about the words 'moral obligations' and 'moral claim' to suggest that an outcome applying these concepts would be a fair and just one. This is the crux of the exploration in this article: the conflation of morality with the fair and just solution in the resolution of these disputes.

The fragility of this conflation for purposes of the fair and just solution lies in the difficulty encountered in reconciling it with the nebulous and ambiguous nature of morality. Further, a relationship between morality and the fair and just solution has been assumed in the application of morality to the determination of a fair and just solution. The suggestion that a moral justification leads to a fair and just outcome by necessary implication raises many questions such as: on what grounds does it do so? Is morality the proper yardstick by which to determine whether these consensual agreements are fair and just? Whose morality is the yardstick against which to measure moral acts, claims and obligations? Who is to be the arbiter between competing moral claims and how does one rank one moral claim over another?

These unanswered questions serve to undermine the applicability of morality as a proper basis for the determination of cultural property disputes. The attainment of a fair and just solution may not always be served by invocations of morality. Further, the need to invoke morality to satisfy the claimant view that a just and fair outcome has been achieved has not been explored in any depth and thus, the relevance of the conflation for the main protagonists to the disputes remains unclear. This article will argue that morality, as currently applied, is not an appropriate basis on which to determine fair and just solutions. It will conclude by advocating the need for an alternative conceptual framework from which to assess entitlement to restitution claims of Nazi-era looted art; a framework that takes into account claimant needs and experiences as it moves the focus away from a concept 
Debbie De Girolamo - Revised Submission for the IJCP

August 30, 2019

of uncertain utility to one that better responds to fair and just principles in restitution claims.

To reach this conclusion, this article will first speak to the issue of the nature of morality in the context of this study, recalling that this study is concerned with the application of morality in the determination of a fair and just outcome for restitution claims. Second, it will contextualise the concept of fair and just solutions within the parameters of the Washington Principles, an international soft law instrument dealing specifically with Nazi related restitution claims. It will then draw attention to (i) the growing reliance on morality as a justification for decision-making when it comes to restitution decisions, (ii) the gap in both scholarship and practice as to the meaning that is ascribed to the concept as it is applied in this context of restitution claims which ultimately impacts its utility, and (iii) examples of competing moral claims to highlight the difficulties in relying on moral claims and obligations to determine outcome. Having positioned the problematic nature of this reliance, it will explore the claimant voice to determine the extent to which concepts of morality are heard within the claimant narrative: for example, whether morality is promoted, felt and applied when seeking a determination of their claims. It will do so by examining published interview data of three claimants who sought restitution of Nazi confiscated art.

The valuable contribution this article brings to the field lies in its focus on morality as the crutch being used by decision-makers in their determination whether to remedy, through restitution or otherwise, claims involving Nazi looted art. While scholars examining other issues have noted the use of morality in these claims, this article focuses specifically on its problematic use. ${ }^{4}$ It offers an argument that morality should not be the basis on which entitlement should be determined, primarily due to its amorphous nature and undefined relationship to justice. This becomes more compelling when the claimant voice is considered. From the

\footnotetext{
${ }^{4}$ For example, see Oost 2018; Campfens 2019.
} 
Debbie De Girolamo - Revised Submission for the IJCP

August 30, 2019

interview data examined in this article, morality does not appear to be a factor that influences claimants' views as to whether an outcome is fair and just. The claimant narrative suggests that concepts of reconciliation and procedural fairness are of concern to claimants rather than recognition of moral entitlement. This is important for the field because it indicates that, in the search for an appropriate conceptual framework for the fair and just solution, regard must be had to these claimant concerns. And, finally, while the exploration in this article references Nazi looted art, its findings are applicable to cultural property claims of other contexts such as colonial or war-time looting, another fertile ground of claims such as those relating to the Maqdala Treasures or the Benin Bronzes, which often also rely on moral arguments for restitution or repatriation claims. ${ }^{5}$

\section{Morality: The defining context}

One might well consider the need for a definitional underpinning to the word morality in this article, especially since its subject matter is about the evolving application of morality to the issue of restitution of Nazi looted art, and one of its criticisms is its invocation by scholars, policy-makers and decision-makers without articulation of its meaning. Morality, however, is not per se the subject matter of this article in the sense of being a philosophical treatise on what constitutes a moral claim and moral action. Rather, this article seeks to highlight the amorphous use made of the word and its lack of definitional boundary in the context of these disputes.

A paradox is presented by this article: it challenges the increasing invocation of morality as a basis for restitution where no meaning is ascribed to it in doing so, yet it has no intention to offer a definition of morality that could be applied to its use. Morality is a value-laden term cutting across definitional boundaries. It does not

\footnotetext{
${ }^{5}$ For example, see Merryman 1985 in which he considers the moral argument in the context of the Parthenon Marbles. Further, for a brief summary about the Maqdala Treasures and Benin Bronzes, see Shyllon 2015.
} 
Debbie De Girolamo - Revised Submission for the IJCP

August 30, 2019

matter which definition would be ascribed to morality in this study by the author: it would merely add another definition to an already crowded field. As legal

philosophers have found, there is no universally accepted definition or approach to morality or moral theory, even at the very basic level of whether a definition is descriptive or normative in nature which impacts its claims, applicability and enforcement. 6 Approaches also differ. For example, Perry considers the concept of morality within legal discourse, noting different underlying premises to the concept: one that is steeped in religious beliefs, and more particularly, in the belief of God; another that sees it as a secular term; or as one fueled by self-interest, emotions or for a concern for humanity. ${ }^{7}$

Even in other philosophical literature that offers a similar underpinning to morality as a concept embedded in a social construct, differences appear. Kedar says that morality comes from interpersonal relationships based on humanity. ${ }^{8}$ Gert sees morality as an informal public system applying to rational persons which governs behaviours, comprised of two aspects: the everyday which might result in disagreements that would be determined by political or legal actions; and ten common rules which reflect primary ideals. ${ }^{9}$ Green sees morality as depending on a social group's beliefs and the values and norms they espouse. ${ }^{10}$ As such, he says morality is fluid, is subject to change when circumstances change, and therefore is fallible. ${ }^{11}$ We see that these views, while all ostensibly premised on a social framework, differ in their approach to the concept: morality is part of the universe of humanity; it is a public system comprised of rational beings who in their everyday disagreements turn to the law or politics for solution and are bound to the greater good by ten rules; or it based on social norms and beliefs, subject to fluctuation. Many concepts are evident in just three examples: the humanitarian, the legal, the religious and the social. Each provides an alternative framework of interpretation.

\footnotetext{
${ }^{6}$ Gert and Gert 2017.

7 Perry 2000, 96.

${ }^{8}$ Kedar 2011, 107.

${ }^{9}$ Gert 1999, 13-14.

10 Green 2013, 479.

11 Green 2013, 474-75.
} 
Debbie De Girolamo - Revised Submission for the IJCP

August 30, 2019

Other problems with the concept have also been noted. Merryman, like Green, sees a connection between society and morality with particular focus on the temporal nature of moral tenets. In the consideration of the issue of the restitution of the Parthenon Marbles to Greece, he considers morality at the time the Marbles were taken from Greece, both in terms of the morality of Lord Elgin's acts and the treatment of cultural property generally by nation states and looters alike, thereby suggesting that morality is defined by the age within which the act was carried out. ${ }^{12}$ Pauer-Studer considers the manipulation of social morality by the Nazi government in shaping its laws to ensure compliance with them, suggesting that morality is not a secure guideline.13 Further, Berkowitz and Walker, in an experiment to gauge the impact of laws and society on moral judgments, found that peer pressure had greater impact in the formulation of moral judgments than knowledge of the law, implying that it is the morality of the powerful which impacts decisions about what constitutes morality. ${ }^{14}$

These are but a few brief examples which illustrate a complexity to the nature of morality that gives rise to its problematic use in the determination of the fair and just solution. Its fluidity and shape-shifting presents a questionable justification for restitution. While morality may seemingly offer a rationale for the restitution of Nazi looted art particularly in view of the heinous acts committed by the Nazi regime giving rise to these claims, its nature is indeterminate, opaque, and ad hoc. Continual reliance on morality as the basis for restitution does not respond to dilemmas facing those who make claims or those defending such claims entitlement to restitution remains unclear. As such, it is an inadequate basis upon which to promote restitution in all circumstances. Claimants, possessors of artworks, adjudicators, facilitators, advisers and society generally, deserve better.

\footnotetext{
12 Merryman 1985, 1909.

13 Pauer-Studer 2012, 370.

14 Berkowitz and Walker 1967, 421.
} 
Debbie De Girolamo - Revised Submission for the IJCP

August 30, 2019

\section{The Washington Principles and the fair and just solution}

This article will not go over terrain that is repeated extensively in the literature dealing with the restitution of looted art: for a detailed review of the legal framework or soft law instruments, resolutions and declarations dealing with cultural property, attention can be directed to many works explaining them in detail. ${ }^{15}$ Rather, its focus is on the words 'fair and just' as introduced by the Washington Principles in the context of Nazi looted art and the impact of these words in the evolution of the moral principles guiding their objective.

The 1998 Washington Conference Principles on Nazi-Confiscated Art (Washington Principles) which were agreed by 44 nations participating in a US led initiative to deal with the difficulties arising with the restitution of Nazi-era looted art, set the goal in such claims to be the achievement of a fair and just solution. ${ }^{16}$ No one would doubt that all claims for the return of such art should be resolved in a fair and just manner whether that is through consensual means or adjudication. The relevance of the Washington Principles is that they call on nation-states to create alternative dispute resolution processes in line with these principles. ${ }^{17}$ As such, they seek to offer soft law norms for the consideration of restitution issues surrounding Nazi looted art. Some countries have done so including the United Kingdom, Germany, the Netherlands, Austria and France through the establishment of state-sponsored restitution committees charged with the determination of such looted art claims. ${ }^{18}$ However, the Washington Principles, alone, do not assist with an assessment of what is fair and just. Their difficulty is that they refer to the need to be fair and just in resolving such disputes, but that is all they say: they do not define these words,

\footnotetext{
15 For example, Kreder 2011; O’Donnell 2011, 51-72; Chechi 2014, 75-76; Demarsin 2010; Graefe 2010; O'Connell 2008; Plachta 2019. While there are soft law instruments dealing with cultural property generally, there are no such instruments which provide clear guidelines for Nazi looted art claims: see Campfens 2019, 95-96.

16 See discussion of the 1998 Washington Conference in Chechi 2014, 67, 267; Mullery 2010, 651;

Demarsin 2011, 136-140.

17 Washington Conference Principles on Nazi-Confiscated Art, Article 11 at http://www.state.gov/p/eur/rt/hlcst/122038.htm

18 Campfens 2015, 41-89; Burris 2016; Oost 2012.
} 
Debbie De Girolamo - Revised Submission for the IJCP

August 30, 2019

and in fact, the Principles acknowledge that what is just and fair will change according to the particular circumstances of each claim. ${ }^{19}$ Sections 8 and 9 of the Washington Principles state as follows:

8. If the pre-War owners of art that is found to have been confiscated by the Nazis and not subsequently restituted, or their heirs, can be identified, steps should be taken expeditiously to achieve a just and fair solution, recognizing this may vary according to the facts and circumstances surrounding a specific case.

9. If the pre-War owners of art that is found to have been confiscated by the Nazis, or their heirs, cannot be identified, steps should be taken expeditiously to achieve a just and fair solution. ${ }^{20}$

While the Washington Principles themselves do not assist in defining what is fair and just, the concept of morality seems to underpin the phrase. In dealing with art claims from the Nazi era, as a result of the Washington Principles and the guidelines established for that purpose, as will be seen, the processes implemented under their edict often involve a consideration of the strength of the claimant's moral claim to the property, and the extent of the moral obligation on the possessor to return the property, all as part of the 'fair and just' solution.

\section{Morality as a marker for the fair and just solution: a growing reliance on the word}

Through the application of the Washington Principles, concepts of morality have become increasingly relevant for the resolution of these disputes as stated above. The UK Spoliation Advisory Panel (SAP) is an excellent example of this where the Panel may determine the moral strength of a claim. ${ }^{21}$ Woodhead considers the past

\footnotetext{
${ }^{19}$ Campfens 2015 which explores this aspect of the Washington Principles in depth; See also, Demarsin 2011, 138-139; Campfens 2017, 316.

20 Washington Conference Principles on Nazi-Confiscated Art at http://www.state.gov/p/eur/rt/hlcst/122038.htm

${ }^{21}$ Spoliation Advisory Panel (SAP) and its Constitution and Terms of Reference at <www.gov.uk/government/groups/spoliation-advisory-panel>; copies of Spoliation Advisory Panel Reports at www.gov.uk/government/collections/reports-of-the-spoliation-advisory-panel. SAP Constitution and Terms of Reference state the aim of the SAP is to reach a fair and just outcome for all parties; see Article 14. In its consideration, among other factors, SAP is to have regard to morality:
} 
Debbie De Girolamo - Revised Submission for the IJCP

August 30, 2019

recommendations of the SAP and its heavy reliance on morality and concludes that the SAP has developed a concept of moral title in the determination of entitlement to cultural property. ${ }^{22}$

When its terms of reference are reviewed, it is seen that morality is only one of many factors that the SAP is required to consider. ${ }^{23}$ Many of the other factors, arguably, reside within a legal framework such as consideration of factual and legal matters, statutory provisions, validity of title. ${ }^{24}$ Until July 2016, the evaluation of moral obligation had an underbelly tinged with legal merits: moral obligations of the respondent were to be considered in light of the acquisition of the property and the institution's knowledge as to the validity of its provenance, all of which made an assessment of moral superiority a multi-dimensional endeavour. ${ }^{25}$

Prior to July 2016, its Terms of Reference had regard to not only the moral title of the claimant, but also, as noted above, the moral obligations of the institution. The Panel, in its pursuit of the fair and just solution, was required to 'give due weight to the moral strength of the claimant's case' and 'consider whether any moral obligation rests on the institution," with the moral requirement remaining undefined. ${ }^{26}$ This two-fold morality requirement changed with revised Terms of Reference, July 2016 when the moral obligation of the institution appears to have been downgraded and taken out of the specific factors that the SAP is to consider: now it will only consider whether 'any particular moral obligation rests on the

see Articles 9, 15(e) and 16. For discussion about SAP and its decisions, see Woodhead 2015; Woodhead 2014; O’Donnell 2011, 77-78; Palmer 2001, 515-518; Bandle and Theurich 2011, 37. 22 Woodhead 2015; Woodhead 2016.

${ }^{23}$ Articles 8, 9, 14, 15 and 16, SAP Constitution and Terms of Reference at www.gov.uk/government/groups/spoliation-advisory-panel

${ }^{24}$ Article 15 SAP Constitution and Terms of Reference sets out a non-exhaustive list of factors. Please see at www.gov.uk/government/groups/spoliation-advisory-panel

25 Article 15(g), SAP Constitution and Terms of Reference, pre-July 2016 at https://assets.publishing.service.gov.uk/government/uploads/system/uploads/attachment_data/fil e/415966/SAP_-_Final_Report.pdf. In other words, SAP was to explore, along with other factors, to what extent the institution took risks in acquiring cultural property that it knew or reasonably ought to have known was not appropriately on offer.

26 SAP Constitution and Terms of Reference, pre-July 2016 found at https://assets.publishing.service.gov.uk/government/uploads/system/uploads/attachment_data/fil e/415966/SAP_-_Final_Report.pdf; 
Debbie De Girolamo - Revised Submission for the IJCP

August 30, 2019

institution' if it is necessary to do so in the course of ensuring a fair and just

solution. ${ }^{27}$ This raises an interesting issue: morality is to be definitely considered in relation to the claimant, but is not to be considered in the same manner with respect to the respondent's position as previously required. A distinction is made between parties in respect of the weight of the moral factor. The criteria regarding morality are no longer mandatory in the normal course as against the institution which holds the art. As a further point, both iterations of the SAP Terms of Reference speak only to the moral strength of the claimant's title, and not to the moral strength of the respondent's title (it is the moral obligation of the respondent that is examined, not its moral entitlement). Both iterations also fail to define morality for purposes of the assessment of moral strength or obligation.

This raises the question whether the moral strength of the respondent's title should also be considered for the sake of a fair and just solution. It will be seen later in the article that competing moral claims between museum and individual may occur in respect of Nazi looted art. Is it fair and just to consider the moral strength of the claimant's position but not the moral strength of the response or the moral obligation of the respondent unless necessary? Further, what does it mean to have a moral claim? In Woodhead's review of SAP decisions, it appears that the most that can be offered by way of definition is that a direct seizure by the Nazi's offers a strong moral claim, while a forced sale depends on 'moral severity'. ${ }^{28}$ These decisions do not engage in establishing the framework of the moral claim - at most, it is circumstantial, to be determined case by case. The concept remains elusive despite its use. The most that can be gleaned is the answer - it depends. These issues are reflective of the problematic use of the moral factor in the consideration of these claims.

\footnotetext{
27 SAP Constitution and Terms of Reference revised July 2016, Articles 15 and 16 at www.gov.uk/government/groups/spoliation-advisory-panel

28 Woodhead 2016, 389-90.
} 
Debbie De Girolamo - Revised Submission for the IJCP

August 30, 2019

The use of the moral factor is not limited to SAP use. Oost too sees a shift from a legal paradigm to a moral paradigm in the work of the Dutch restitution committee. ${ }^{29}$ This, together with the work of other various European Restitution Committees where fair and just is often considered in relation to moral obligations and entitlements, suggests an institutionalization of a morality requirement. ${ }^{30}$ Additionally, O'Donnell sees the concept of moral duty as having been accepted by the art world in dealing with issues of Nazi-era looted art and restitution. ${ }^{31}$ Joan Troccoli, Deputy Director of the Denver Art Museum, for example, says on voluntarily restituting cultural property to a victim of Holocaust looting: "We felt we had a moral responsibility to be responsive to claims, which was just as important as our legal obligations." 32 This seems to support Campfens' suggestion that moral norms are gaining ground through soft law instruments such as ethical codes. $^{33}$

With such references to moral rights and duties in the consideration of reaching fair and just outcomes, it would appear that morality has taken on a normative construct of justice. ${ }^{34}$ Even so, it fudges the question as to whether the invocation of moral rights to support restitution claims leads to a fair and just outcome. Perhaps, at its simplest, morality and justice in this context become the same thing because the act of returning an item that does not belong to you, but belongs to the person who has suffered greatly by its loss can be easily understood. However, as the scholarship

\footnotetext{
29 Oost 2018.

${ }^{30}$ For discussion about the exploration of the concept of fair and just and the various restitution committees, with particular emphasis on the Dutch Restitution Committee, see Campfens 2015; Campfens 2014, 88; Roodt 2013, 444 suggests that the issue of morality impacts the type of outcome that would be considered to be just and fair, proposing that the invocation of moral duty requires a return the property rather than alternative compromise. For an overview of the work of several European Restitution Committees, see Demarsin 2011, 159, 170-181.

31 O’Donnell 2011, 78; see also Nudelman 2015, 1283-84.

32 Palmer 2001, 527 where Palmer quotes Troccoli from a private conversation he had with Troccoli in January 2001.

33 Campfens 2014, 62-63; see also, Reppas 2007, 120 where Reppas suggests the creation of a new 'morality' norm.

${ }^{34}$ See also, Campfens 2014, 72 where she suggests that moral obligations were also relevant to the determination of restitution cases involving pre-1970 lootings under UNESCO's soft law provisions See also Oost 2018 in which Oost discusses the moral considerations taken by SAP and the Dutch Restitution Committee which have become part of their institutional policies.
} 
Debbie De Girolamo - Revised Submission for the IJCP

August 30, 2019

indicates, simplicity is not a characteristic of cultural property disputes. These are not easy claims to reconcile: Willi Korte, an American lawyer specializing in art claims, speaks of the difficulty of pursuing such art claims: "you're asking someone for something in exchange for nothing-except acknowledgment of their moral obligation to return a work of art."35

\section{A lack of definitional boundary}

Just as the Washington Principles do not offer much guidance on what is fair and just, rarely does the scholarship on the evolution of the moral claim in restitution disputes define morality, moral duty, or moral obligation. The literature dealing with the restitution of Nazi-looted artwork speaks broadly of morality. For example, in titles and introductions, it speaks of ethical dilemmas and the importance of moral precepts to guide the return of such cultural property. It rarely, if at all, attempts to consider what is the morality that it refers to. ${ }^{36}$ For example, Oost, in placing the work of the SAP and Dutch Restitution Committee within a moral paradigm, assumes morality as an understood concept, without definitional boundary. ${ }^{37}$ She argues that morality lacks clear standards which does not provide a good basis on which these committees should proceed to determine restitution claims. ${ }^{38}$ Campfens too assumes it as an understood concept, without definitional boundary, seeing the difficulty with its use; more particularly, she refers to morality as a 'vague norm' dependent on power, commercial interests or political motivations, and as such, sees the need for clear norms to determine looted art claims. ${ }^{39}$ Implicit in the discussion is a view that, while it is understandably used as

\footnotetext{
35 Susan Baer, "Searching for Masterpieces" in Washingtonian, 1 November 2009 at < http://www.washingtonian.com/2009/11/01/searching-for-masterpieces/>

36 See for example, Kreder 2007; Skinner 2013; Soltes 2016.

37 Oost 2018. See also, Campfens 2017. This lack of definitional boundary to the concept of morality is not prevalent in cultural property studies only. It is also evident in the context of other cultural studies: See for example Nielsen, Patel et al. 2017 where the search for morality in film occurs without a definitional framework.

38 Oost 2018, 161, 173.

${ }^{39}$ Campfens 2014, 88; Campfens 2017, 343 where Campfens states that Nazi looted art has 'obviously moral aspects'.
} 
Debbie De Girolamo - Revised Submission for the IJCP

August 30, 2019

justification for restitution in Nazi looted claims, its nature remains elusive.

Morality is sometimes used in the context of determining right and wrong such as was used by the Seattle Art Museum when returning a Matisse to the heirs of a Holocaust victim: "By our action today, the Seattle Art Museum is drawing a clear ethical line. Since day one, SAM has been committed to doing the right thing." 40 Doing the right thing is often described as moral obligation. ${ }^{41}$ Tiffany Jenkins argues that there is an internal struggle within museums between the need to fulfill a museum's role and the need to do the 'right thing' when faced with an issue of repatriation or restitution of cultural property. ${ }^{42}$ Is then the fulfillment of a moral obligation 'doing the right thing' or should we look at the underlying reason for the fulfillment of the moral obligation?43 Doing the 'right thing' does not help because similar considerations apply to this phrase as do to morality: what is the 'right thing' to do; what values should underpin it; and who should be the final arbiter on what is the 'right thing' to do.

Ethical codes to which museums are often subjected, also do not appear to assist in defining moral obligation. For example, the Code of Ethics for the International

\footnotetext{
40 Press Statement of the AAMD - SAM to Return Matisse Odalisque to Rosenbergs - 14 June 1999 at < https://plone.unige.ch/art-adr/cases-affaires/odalisque-painting-2013-paul-rosenberg-heirs-andseattle-art-museum/press-statement-of-the-aamd-sam-to-return-matisse-odalisque-to-rosenbergs14-june-1999/view> . For full details of the case, see Alessandro Chechi, Raphael Contel, Marc-André Renold, "Case Odalisque Painting - Paul Rosenberg Heirs and Seattle Art Museum," Platform ArThemis (http://unige.ch/art-adr), Art-Law Centre, University of Geneva at < https://plone.unige.ch/art-adr/cases-affaires/odalisque-painting-2013-paul-rosenberg-heirs-andseattle-art-museum>

${ }^{41}$ See for example, Marilyn Phelan, "Legal and Ethical Considerations in the Repatriation of Illegally Exported and Stolen Cultural Property: Is there a Means to Settle the Disputes" at <http://media.rcip-chin.gc.ca/ac/intercom/phelan.html > where Phelan states that museums have acknowledged a moral obligation to return artworks, and refers to the Virginia Museum of Fine Arts' statement that the return of a particular painting was 'simply the correct thing to do' at 4 \& 11; see also Markowitz 2012 in referring to a dispute between the Grand Ronde Tribe and the American Museum of Natural History for the return of the Willemette Meteor where the Museum instituted legal action. Markowitz refers to the Grande Ronde Tribe wanting the museum to 'do the right thing' at 243.

42 Jenkins 2016.

${ }^{43}$ Fincham and Chechi speak about museums doing the right thing to avoid shaming, and adverse publicity: Fincham 2013b, 216; also available at SSRN: http://ssrn.com/abstract=2297954; Chechi 2014, 190-191 who suggests a similar motivation when 'doing the right thing'.
} 
Debbie De Girolamo - Revised Submission for the IJCP

August 30, 2019

Council of Museums (ICOM Code) does not refer to either morality or 'doing the right thing' when speaking of the return of cultural property. Specifically, Articles 6.2 and 6.3 state:

6. 2 Return of Cultural Property

Museums should be prepared to initiate dialogues for the return of cultural property to a country or people of origin. This should be undertaken in an impartial manner, based on scientific, professional and humanitarian principles as well as applicable local, national and international legislation, in preference to action at a governmental or political level.

\section{3 Restitution of Cultural Property}

When a country or people of origin seeks the restitution of an object or specimen that can be demonstrated to have been exported or otherwise transferred in violation of the principles of international and national conventions, and shown to be part of that country's or people's cultural or natural heritage, the museum concerned should, if legally free to do so, take prompt and responsible steps to cooperate in its return. ${ }^{44}$

It seems to be accepted in the literature that morality is a sufficient marker for achieving fair and just solutions, yet it is a marker that sits ambiguously within a broader justice framework. The current use of morality in the field seems to presuppose that morality is a unique social phenomenon, distinct from legal rules defined by state law. It falls neither within a legal framework of justice as theorized by John Rawls for example, nor does it fall within other concepts of justice: popular, restorative or procedural justice, for example. The goal of the Washington Principles is the fair and just solution which seems to assume that a fair and just solution delivers justice, yet there is a lack of consideration of what form justice should take in the consensual resolution of these cultural property disputes. Perhaps that might explain the readiness with which the fulfillment of a moral obligation has taken on the context of a fair and just outcome.

It is rare that the literature offers an analysis of the fair and just solution through a justice framework. Some scholars have attempted to do so including Fincham,

\footnotetext{
44 International Council of Museums Code of Ethics for Museums, 2013 Version at
} http://icom.museum/fileadmin/user_upload/pdf/Codes/code_ethics2013_eng.pdf 
Debbie De Girolamo - Revised Submission for the IJCP

August 30, 2019

Palmer and Weller. Fincham argues for cultural justice, referring to Rawlsian concepts of the original position and the veil of ignorance as the starting point for establishing rules of society, and placing these concepts within an environmental justice framework from which to assess distributive, procedural, corrective and social justice concerns of the cultural property dispute. ${ }^{45}$ While not speaking in the context of the just and fair solution, Fincham brings attention to the various aspects of justice that can impact the resolution of the art dispute and applies many aspects of justice in his consideration. Palmer, on the other hand, looks to the underlying premise of the fair and just solution, relying on general 'well-known tenets of justice' such as an impartial resolution, a speedy resolution of issues, approaching claims on their merits, which he says combine substantive and procedural justice concerns. ${ }^{46}$

Although Fincham and Palmer seek to place the issue within a justice dialogue, their expositions appear to be broadly conceived. Weller's exploration of the fair and just solution in light of the relationship between law and justice offers a more targeted view. He states that abstract concepts of justice as currently exist do not assist in finding just and fair solutions, necessitating a reworking of restitution principles in order for justice to be possible. ${ }^{47}$ For Weller, these principles should focus on procedural legitimacy requiring the following: a reputable decision-maker; rules established by those not adjudicating the claims; public trust in the system; set procedural rules; and publicly available reasoning to support the decisions. ${ }^{48}$ Fincham, Palmer and Weller recognise the need for parameters around the concept of justice as applied to restitution claims. Fair and just must sit within a justice framework to be viable. The current deficiency is augmented when adding the

\footnotetext{
45 Fincham 2012; Fincham 2013a also refers to Rawls and cultural justice on the issue of the Parthenon Marbles .

46 Palmer 2015, 167-173.

47 Weller 2015, 206. In considering substantive justice elements of fair and just solutions, Weller relies on Dworkin and the need for identification of fair and just principles for the interpretation of the law; see at 201-206.

48 Weller 2015, 207-9 where Weller relies on Luhmann's arguments regarding the need for procedural legitimacy.
} 
Debbie De Girolamo - Revised Submission for the IJCP

August 30, 2019

value-laden use of morality to the notion of the fair and just solution without establishing its role and function within a justice system.

Morality is a complicated concept particularly when examining it in relation to a legal framework pursuant to which these claims arise: adherents to natural law theory will see the connection between law and morality in that laws are steeped in morality; ${ }^{49}$ while the positivists theorists see the necessity of separation between law and morality where there is no place for morality in a legal system. ${ }^{50}$ Yet even further, communitarians see morality emerging from shared experiences, with law being underpinned by community values. ${ }^{51}$ This serves to illustrate an ambivalent relationship between law and morality and provides an insight as to why morality does not fit easily within a justice system as suggested by the words of the Washington Principles and its fair and just solutions. As such, its role as providing a premise for fair and just solutions is questionable. As Norman Palmer stated: "Justifications must be capable of withstanding the most searching analysis. Only by that means will it become possible to treat like cases alike and offer coherent guidance to future claims. Anything short of that will bring a system of resolution, however well-meaning and well-resourced, into significant disrepute."52

\section{In the face of competing claims}

Kreder sees the futility of relying on morality to guide the resolution of cultural property claims, particularly in the context of Nazi-era looted art because moral

\footnotetext{
${ }^{49}$ For discussion about natural law theory, see Fuller 1969; Finnis 1980; Dworkin 1997 where he criticizes positivist theory, speaking to a community of values.

50 For the positivist theory, see Hart 1997; Rawls 1971.

51 For works discussing communitarian theory, see Walzer 1983; O'Manique 2003; Sandel 1982; Glendon 1991; for a discussion exploring the difference between the positivist and communitarian approach to law and morality, see Gonthier 2003 in which Gonthier, former Lord Justice of the Supreme Court of Canada, connects law with the values of a community; Atkinson 2002/03 revisits the communitarian critique of positivism.

52 Palmer 2015, 169. While Palmer appears to make this quote in relation to decisions of restitution committees, it remains applicable generally, particularly in view of the use of morality in their decisions, as discussed earlier in this article.
} 
Debbie De Girolamo - Revised Submission for the IJCP

August 30, 2019

views vary. ${ }^{53}$ She uses two restitution cases to highlight the need for guidelines by which fair and just solutions can be determined. For those guidelines, she turns to ICOM's Code to consider museum obligations and ethics in the context of restitution claims against the Auschwitz-Birkenau State Museum (ABSM) in Poland made by a survivor to the Holocaust and the other by the heir of a Holocaust victim.

The Kreder examples are worth considering in some detail for purposes of this article. In both cases, the moral arguments for and against restitution are compelling. Both arise out of Holocaust era atrocities. The first claim concerns that of Pierre Levi's son who requested the return of his father's suitcase from the ABSM. ${ }^{54}$ Levi's son recognized the suitcase when it was on loan to the Paris Foundation for Remembrance of the Shoah (Paris Shoah Foundation). His father died in Auschwitz. The ABSM at first refused to return the suitcase by denying Levi's ownership claim, attempting a legal obstacle to its return. It eventually agreed to compromise by loaning the suitcase to the Paris Shoah Foundation for an indefinite basis in exchange for the ownership of the suitcase to remain with ABSM. The ABSM's opposition was steeped on a premise of keeping alive the history of the genocide at the very place it occurred by maintaining the integrity of all items found at the camp. ${ }^{55}$ Levi's son wanted the suitcase to be in a museum for all to see, but did not want it to undergo another trip back to Auschwitz - once was enough. 56 Both positions can be said to be morally valid - one for individual reasons and the

\footnotetext{
53 Kreder 2008, 5-6. Indeed, the Washington Principles acknowledge this given their wide scope of discretion; see Article 8.

${ }^{54}$ Kreder 2008, 23-25. For another full summary of the chronology and accompanying documents, see Case Auschwitz Suitcase - Pierre Lévi Heirs and Auschwitz-Birkenau State Museum Oswiecim and Shoah Memorial Museum Paris, by Anne Laure Bandle, Raphael Contel, Marc-Andre Renold, ArThemis Art-Law University of Geneva, March 2012 at < https://plone.unige.ch/art-adr/casesaffaires/auschwitz-suitcase-2013-pierre-levi-heirs-and-auschwitz-birkenau-state-museumoswiecim-and-shoah-memorial-museum-paris/case-note-auschwitz-suitcase> 55 Case Auschwitz Suitcase - Pierre Lévi Heirs and Auschwitz-Birkenau State Museum Oswiecim and Shoah Memorial Museum Paris, by Anne Laure Bandle, Raphael Contel, Marc-Andre Renold, ArThemis Art-Law University of Geneva, March 2012 at < https://plone.unige.ch/art-adr/casesaffaires/auschwitz-suitcase-2013-pierre-levi-heirs-and-auschwitz-birkenau-state-museumoswiecim-and-shoah-memorial-museum-paris/case-note-auschwitz-suitcase>; see also, Kreder 2008, 27-29; Messer 2008.

56 Kreder 2008, 24.
} 
Debbie De Girolamo - Revised Submission for the IJCP

August 30, 2019

other for social reasons. In this case, the parties were able to reach a compromise; however, in the second example, the dispute remains outstanding.

The second dispute involving a similar competing moral claim deals with the Babbitt watercolours. ${ }^{57}$ Dina Babbitt was a prisoner of Mengele at Auschwitz during the Holocaust and to save her life and that of her mother, she agreed to paint prisoners as requested by Mengele. At issue are seven watercolours of Roma and Sinti prisoners. Babbitt claimed their return as they are a reminder of her survival and represent her need to retain what belongs to her after having had everything taken away from her. ${ }^{58}$ The ABSM opposes the return on the basis of legal ownership and for similar reasons as articulated in the Levi claim. ${ }^{59}$ In particular, when reviewing the Babbitt claim again in 2009, the International Auschwitz Council stated as follows:

The members of the Council returned once again to the issue of the seven Roma portraits painted by Dina Gottlieb-Babbitt. The Council emphatically reiterated its previous determination that the transfer of the originals to Mrs. Gottlieb-Babbitt, as she demands, is out of the question.

Members of the Council stressed that, in this and all similar cases, the overriding consideration is the authenticity and completeness of the Memorial, with all its movable and non-movable property. The portraits in question were painted in the camp, on orders from Dr. Josef Mengele, as documentation for his pseudoscientific racist research. Today, they are among the very few remaining vestiges of the murdered Roma, and cannot be replaced by any copies. Respect for this principle makes it possible to avoid any sort of doubts that could be cynically exploited in the future by deniers. It must be stressed once again that the International Auschwitz Council has already expressed its position on these paintings. On a motion by Rabbi Andrew Baker, the issue was voted on once again. ${ }^{60}$

\footnotetext{
57 For a detailed summary of the Babbitt claim, see Kreder 2008; Messer 2008.

58 Kreder 2008, 21-23.

${ }^{59}$ Kreder 2008, 25-29.

${ }^{60}$ See report of the Council Meeting of June 15-16, 2009 at < http://auschwitz.org/en/museum/auschwitz-council/iac-meetings/meeting-xvii-15-16-june2009,17.html>
} 
Debbie De Girolamo - Revised Submission for the IJCP

August 30, 2019

The case remains unresolved, despite years of litigation. Babbitt has died without a return of the paintings; her heirs continue the struggle. ${ }^{61}$ This dispute can also be said to involve two valid moral claims, with each party strongly believing in the superiority of their claim. Their competing moral claims have led to a stalemate between the parties. As Rabbi Andrew Baker, then director of International Jewish Affairs for the American Jewish Committee and a member of the International Auschwitz Council, which advises the Auschwitz museum said: "The people at the Polish museum aren't devils. They want to maintain Auschwitz as authentically as they can, and I can appreciate the role exhibiting the paintings plays. What I've always thought is there is no one else in the world who so values these paintings as Dina Babbitt and the directors of this museum."62

While Kreder uses these examples to argue the relevance of the ICOM Code as providing a sufficient framework for restitution claims such as these, it should be noted that she makes very persuasive argument of the superiority of the claimant's moral claim over that of the Museum. Having said this, however, one can argue that a moral dilemma exists in both cases, and the dilemma rests on one's view of morality and its underlying values. ${ }^{63}$ For example, the mainstream media illustrated the dichotomy of views: Tom Sutcliffe, BBC commentator on a radio programme about the ownership of culture, said of Nazi-era spoliation restitution: "It is a no brainer. No one will say..." - a statement with which many would agree. ${ }^{64}$ However, another view was suggested by Dr Tiffany Jenkins, guest commentator on the

\footnotetext{
${ }^{61}$ Larry Gordon, "Dina Gottliebova Babbitt dies at 86; Auschwitz survivor fought to regain portraits she painted there" August 1, 2009, Los Angelas Times, at < http://www.latimes.com/nation/la-medina-babbitt1-2009aug01-story.html>; Dina Babbitt, Obituary, The Telegraph, August 14, 2009 at http://www.telegraph.co.uk/news/obituaries/culture-obituaries/art-obituaries/6029766/DinaBabbitt.html; David B. Green, This Day in Jewish History 1923: Czech Woman Who Drew Fellow Auschwitz Inmates Is Born, Haaretz, January 21, 2014 at http://www.haaretz.com/jewish/this-dayin-jewish-history/.premium-1.569756; Elissa Einhorn, "In Auschwitz, she was forced to paint. Now her family wants her art returned" August 15, 2017, The Jewish News of Northern California at <https://www.jweekly.com/2017/08/15/auschwitz-forced-paint-now-family-wants-art-returned/> 62 Bruce Weber, "Dina Babbitt, Artist at Auschwitz, Is Dead at 86" New York Times, August 1, 2009 at < http://www.nytimes.com/2009/08/02/arts/02babbitt.html?_r=0>

${ }^{63}$ Messer also speaks to the competing moral claims illustrated by this example; Messer 2008, 29-30, 34.

${ }^{64}$ Sutcliffe's quote trails off here. It suggests a view that sees the moral claim as requiring restitution in this scenario.
} 
Debbie De Girolamo - Revised Submission for the IJCP

August 30, 2019

programme, who responded: "It may be a no-brainer, but it is not straightforward.

It is not to say things returned to individuals are better there; they may be better in a museum."65 The recent decision of the UK government to fund trips by student and university leaders to Auschwitz as a way to tackle anti-Semitism and racism on university campuses gives colour to the complexity of the debate. ${ }^{66}$ Students experienced, first hand, the horrors of the Holocaust during their visit to Auschwitz in November 2018 as part of this funded project, with one student leader saying: "As citizens, this is part of our history, and we need to ensure that nothing like this happens again. I hope I will be brave enough to speak out and challenge behaviour."67 It was their trip to the ABSM which elicited such reaction.

In this debate, some will argue that the victim's claim trumps the public interest claim, and this cannot be said to be wrong. Some will argue that the preservation of the collective consciousness in the very place where loss occurred trumps the individual claim, and this cannot be said to be wrong. These are two conflicting and meritorious opinions. Who, however, is to decide which is the superior opinion, which is the more fair and just view? Ultimately, something more than morality is needed because it is clear from these two scenarios, that morality does not always provide for a fair and just resolution.

These examples pit two, ostensibly valid moral claims against one another - one of the individual victim of Nazi atrocities against a public interest for the preservation

65 BBC Radio 4, Start of the Week, chaired by Tom Sutcliffe, "Who owns culture?" with panelists, Dr Tiffany Jenkins (Jenkins 2016), Tendai Huchu, Ellen McAdam and Waldemar Januszczak, Producer Hannah Robins, first broadcast on February 15, 2016 at 9 am available at <http://www.bbc.co.uk/programmes/b006r9xr/episodes/downloads?page=2

66 Press release issued by the Ministry of Housing, Communities \& Local Government, Department for Education, and the Rt Hon Sajid Javid MP, “Government announces $£ 144,000$ of new funding to help universities tackle anti-Semitism on campus" (January 16, 2018) at < https://www.gov.uk/government/news/government-announces-144000-of-new-funding-to-helpuniversities-tackle-antisemitism-on-campus>

${ }^{67}$ Harriet Sherwood, "'Who let this happen?': students rediscover anti-Semitism on Auschwitz field trip", The Guardian, November 21, 2018 at < https://www.theguardian.com/world/2018/nov/21/who-let-this-happen-students-rediscoverantisemitism-on-auschwitz-field-trip> 
Debbie De Girolamo - Revised Submission for the IJCP

August 30, 2019

of a memorial. In a broader context, Kreder's case studies and their competing claims are suggestive of Merryman's dichotomy of cultural nationalism and cultural internationalism. ${ }^{68}$ They epitomize the Merryman stratification between national collective claims and those of worldkind. Merryman, in speaking of the global movement toward defending cultural nationalism for the return of cultural property, argues that the underlying values of cultural internationalism should not be forgotten: in this broader context, the simplicity of the argument for the return of objects to their place of origin is not always a straightforward matter of the protection of cultural identity.

According to Merryman, it is important to balance the interests promulgated by both views: in other words, arguably, the moral obligation of the return of cultural property that forms part of the cultural heritage of a community should not always take precedence over the larger public interest of preservation, education and promotion of universal cultural heritage. ${ }^{69}$ These Merryman arguments have resonance for Nazi era looted art as well: a similar difficulty occurs with the question of how to resolve valid competing interests and moral claims, whether they are reflective of individual or 'worldkind' interests.

\footnotetext{
68 Merryman 1986.

${ }^{69}$ For Merryman's arguments in this regard, see Merryman 1986; Merryman 1989; Merryman 2005; Merryman 1998. Seligman questions this universal museum moral responsibility and in particular, whether museums are 'becoming moral imperialists' as guardians of cultural heritage: see Seligman, 1999, 82-83. On the other hand, Frankel and Forrest make a case for universalism: Frankel and Forrest 2013. Thompson 2011, too, examines the dilemma posed. See also, Kreder 2016. Jenkins 2016 is also a defence of museums and the concept of universality. The book has received mainstream media attention and is published by a reputable academic publisher. The reviews have been harsh. Bowrey 2016, 20-21 states: "This is an opportunistic and dangerous book. ...The book is a defence of a very old-fashioned and conservative view-the idea of a universal 'rationality' where all humanity is shared, where 'treasures' ended up in Europe due to a 'global trade' fuelled by mutual cultural curiosity and, for the most part, property acquisitions were carried out in accordance with civilised property laws." Johanna Hanink, in her review of the book in Bryn Mawr Classical Review (2016.12.06) also castigates Jenkins for her views: see at < http://bmcr.brynmawr.edu/2016/201612-06.html>. While recognizing academic weaknesses to the book, Moser 2017, 530 states: "What Jenkins does bring to the debate is a questioning approach that seeks to look at the benefits of retaining artifacts in museums rather than repatriating them. Hopefully this will encourage further dialogue on the role of cultural artifacts in defining contemporary society." This literature is mentioned to illustrate the complexity of the moral arguments raised by issues of restitution of looted cultural property, both with respect to Nazi-era looting and other illicit looting.
} 
Debbie De Girolamo - Revised Submission for the IJCP

August 30, 2019

These competing interests and views become the fodder for controversy. In 2008,

Sir Norman Rosenthal, former head of exhibitions of the Royal Academy of Arts and

of Jewish heritage whose family suffered under the Nazi regime, suggested that the

restitution of Nazi-era looted art should end: "I believe, however, that

grandchildren or distant relations of people who had works of art or property taken

away by the Nazis do not now have an inalienable right to ownership, at the

beginning of the 21st century. If valuable objects have ended up in the public sphere, even on account of the terrible facts of history, then that is the way it is. ... it has to be good that important works of art should be available to all through public ownership. Restitution claims from museums go against this idea and result in the general culture being impoverished." 70 Rosenthal's comments come in the context of the following particular sentiments he espoused at the time: it is not fair that some victims of the Nazi atrocities receive compensation through restitution claims while others who suffered the same atrocities receive nothing; as the claimants become further removed from the victims of the Holocaust, the entitlement to restitution should be limited; the restitution of art work cannot compensate for the actions taken by the Nazis; the restitution of art has become tainted due to the economic gain that accrues to some individuals because of restitution and the negative impact of this on the art market; and art should be preserved by museums for society as a whole..$^{71}$ This view articulated by Rosenthal at that time subjected him to both vociferous critique and support in the press and scholarship. ${ }^{72}$

\footnotetext{
${ }^{70}$ Norman Rosenthal: The Time Has Come for a Statute of Limitations, The Art Newspaper, December 2008 available at Lootedart.com Blog, Press, television, radio and film: Should Nazi-looted art be returned? at http://www.lootedart.com/NFVA1Y581441_print; Y

${ }^{71}$ SPIEGEL Interview With British Art Expert Norman Rosenthal, "We must live in the Present" April 9, 2009 available at < http://www.spiegel.de/international/germany/spiegel-interview-with-britishart-expert-we-must-live-in-the-present-a-618399.html>. This should be read with the companion piece: Ulrike Knöfel, "A Question of Morality: An End to Restitution of Nazi Looted Art?" April 09, 2009, in SPIEGAL ONLINE, available at < http://www.spiegel.de/international/germany/a-questionof-morality-an-end-to-restitution-of-nazi-looted-art-a-618400.html>

72 The LootedArt blog sets out the Rosenthal article in full as well as several responses to the article and to Jonathon Jones's article in the Guardian which supported Rosenthal's views: available at Lootedart.com Blog, Press, television, radio and film: Should Nazi-looted art be returned? at http://www.lootedart.com/NFVA1Y581441_print;Y. See also, Kreder 2009 in which Kreder reviews museum defences in the context of legal framework, and has reference to Rosenthal's comments.
} 
Debbie De Girolamo - Revised Submission for the IJCP

August 30, 2019

The issue of competing claims also arises when dealing with claims against bonafide purchasers of cultural property. ${ }^{73}$ Bonafide purchasers here refer to those who are innocent of any wrongdoing or negligent conduct in the purchase of the property those, in other words, who have not turned a blind eye to precariously established provenance. How does a consideration of moral entitlement in this scenario lead to a fair and just outcome? Resolution in this scenario may not be as simple as a straight return of the contested property; resolution in this scenario may need a reconciliation of interests for the consideration of a fair and just outcome. Currently, the law deals with the bonafide purchaser: in civil law traditions, the bonafide purchaser may have good title despite the nature of the artwork as stolen whereas the common-law tradition holds that good title to stolen goods cannot be conveyed to a bonafide purchaser. ${ }^{74}$

If one looks at this issue from a moral standpoint, two innocents are again pitted against one another. The morality of the situation may be seen from two perspectives, and ultimately, a subjective call would need to be made as to which has the greater moral claim, how best to compensate the inferior claim who suffers a loss by virtue of the restitution and who should pay for such loss in compensation. Campfens suggests that soft laws lack present day morality to deal with such issues. The comment illustrates the temporal and spatial nature of morality: legislation as it exists today protects the good faith purchaser in certain jurisdictions, and it is physical presence in such a jurisdiction that protects such an owner. This only serves to further highlight the complexity of relying on a moral claim. ${ }^{75}$

\footnotetext{
73 Graefe 2010; O’Donnell 2011, 69; Chechi 2013, 179-180; Demarsin 2010, 259; Reyhan 2001.

${ }^{74}$ See discussion of the bonafide purchaser in the civil and common law traditions in Directorate General For Internal Policies, Policy Department C: Citizens' Rights And Constitutional Affairs, Legal Affairs, Cross-border restitution claims of art, looted in armed conflicts and wars and alternatives to court litigations, a study by Marc-André Renold, May 2016, available at [http://www.europarl.europa.eu/RegData/etudes/STUD/2016/556947/IPOL_STU(2016)556947_E N.pdf] at $29 \& 30$.

${ }^{75}$ Campfens 2017, 331. Another example illustrating the difficulty of relying on a morality construct for restitution decisions can be found with the determination of fluchtgut claims (sales occurring outside of Germany during the Nazi period but not occurring as a result of a direct Nazi confiscation): see Oost 2018, 159-161; Campfens 2017, 329-331.
} 
Debbie De Girolamo - Revised Submission for the IJCP

August 30, 2019

\section{The claimant voice}

In this movement toward the invocation of morality to achieve a fair and just solution, morality appears to have become a substitution for justice in this context without necessarily an understanding of what this means for those who seek a fair and just resolution of their claims. This is an important absence from the consideration of the efficacy of morality as a driver for the fair and just solution. The Washington Principles speak of fair and just solutions. The Dutch and UK Restitution Committees speak of moral claims. Scholars suggest a generalized conception of morality as justification for successful restitution claims. The key protagonist, however, in all these discussions has not been heard on this issue: the claimant voice has not entered into the debate. What does the claimant expect and require when seeking a return of their claimed property? An exploration of the claimant voice may lead to further understanding about fair and just outcomes and the role that morality should play in the claimant's pursuit of their claims.

In Campfens' edited collection of essays exploring the issue of the phrase 'fair and just' of the Washington Principles, three interviews given by claimants of Nazilooted art are reported, with the aim of determining their view of justice in the pursuit of their claim. ${ }^{76}$ These provide an important introduction into the claimant view of justice as it relates to the fair and just solution. For purposes of this article, these claimant narratives test the applicability of morality as a marker for such a solution. For them, the manner in which they and their claims are treated is important. The concept of morality as a basis for entitlement, whether in terms of superiority of their claim due to the circumstances of their loss or in terms of the

\footnotetext{
${ }^{76}$ Campfens 2015. This research provides a good initial source of interview data conducted of claimants' experiences of a restitution process for a prelimary exploration of claimant needs in relation to moral considerations and the just and fair solution. However, it should be noted that the claimant voice in this connection has not yet been fully canvassed, and therefore is a matter for further research. It should also be noted that the claimants discussed in this article received a satisfactory outcome from their perspective, although they were not satisfied with all aspects of their claims processing.
} 
Debbie De Girolamo - Revised Submission for the IJCP

August 30, 2019

'right thing to do' does not figure prominently in the discussion. Instead, echoes of procedural justice and reconciliation are heard.

(I) The Claimants

(a) Alfred Jacobsen 77

The Jacobsen family made a claim to the Dutch Restitution Committee for restitution of certain artwork. The family had no prior knowledge of the existence of the artwork until notified by the Committee. Jacobsen speaks highly of the care and attention given to his claim by the Dutch Restitution Committee. ${ }^{78}$ He was impressed by the thoroughness of the investigation. ${ }^{79}$ It was critical for him that the claim was 'treated very seriously' and that the claim was considered 'thoroughly and professionally.'80 In speaking of the process he experienced, he is cognizant of the presence of an aspect of justice. As he states, "the questions which occupy me are what is fair and just and how far back should you go."81 Further, he says: "For me, it is not just about the objects, though, it is about the trouble, care and energy it took to do the right thing." 82 Trouble, care and energy speak to process; 'doing the right thing' speaks to outcome.

For Jacobsen, as long as due care is exercised with respect to a claim, a just and fair resolution can be achieved even if the ultimate decision is that no restitution should occur (in his family's circumstance, one claim was refused while others were granted), suggesting that as long as the process is deemed appropriate, 'doing the right thing' also can result in the rejection of the claim. The procedure conducted by the Committee in coming to its decision was important to Jacobsen: his narrative

77 Campfens 2015, 103-107.

78 Campfens 2015, 103-106.

${ }^{79}$ Campfens 2015, 104-105.

80 Campfens 2015, 104.

${ }^{81}$ Campfens 2015, 104.

82 Campfens 2015, 106. 
Debbie De Girolamo - Revised Submission for the IJCP

August 30, 2019

was acknowledged and accepted. Ultimately, process seems to matter for Jacobsen: both in the articulation of the claim by the Committee and its outcome, and also in his honest assessment of the merits of his claims.

\section{(b) Ella Andreisse and Robert Sturm 83}

Andreisse and Sturm made a claim for the return of a Persian carpet that was also subject to a claim by another family. The Dutch Restitution Committee had to consider the two competing claims. It returned the carpet to both families on a $50 / 50$ basis since it could not determine from which family home the carpet was taken. The families then agreed they would jointly decide on the future of the carpet.

The claimants make reference to the government's delay in acting on these claims as a result of which the evidence that would have helped to establish provenance to the carpet was lost through the passage of time. They also felt that something should have been done earlier when the owners were still alive and 'the objects had more emotional value for them than for us' ${ }^{84}$ The family had submitted declaration forms reporting stolen art to the government in earlier attempts (after the war) to seek the return of the confiscated objects. ${ }^{85}$ In respect of these early attempts, the family noted (i) that little had been done by the authorities, (ii) the difficulty of establishing ownership to a high standard of proof that was demanded, (iii) and the requirement that claimants, at the time, pay for storage and transportation costs, all of which were referred to negatively. ${ }^{86}$ The procedure of the Dutch Restitution Committee, however, in handling the investigation carefully, accurately, and fulsomely is "a good example of a fair and just solution". ${ }^{87}$ Resolution for this family meant rectification - the value of the property was received rather than the property itself. "Even

\footnotetext{
83 Campfens 2015, 141-150.

${ }^{84}$ Campfens 2015, 143.

85 Campfens 2015, 142-143.

${ }^{86}$ Campfens 2015, 143.

87 Campfens 2015, 144.
} 
Debbie De Girolamo - Revised Submission for the IJCP

August 30, 2019

though we are a generation further away from Samuel van den Bergh, we can still contribute to a fair and just solution." 88

Again we see process and its thoroughness to be important in the consideration of fairness and justice: the claimants were very satisfied with the Committee's investigation. It appears that their interest is not necessarily restitution but rather acknowledgement of their claim. They need an engagement with their claim. This is illustrated further by their reference to another claim they sought to pursue against private individuals who refused to engage in dialogue with them. This, they felt, was unjust, particularly when they believe they have clear evidence of ownership of the object. 89 In another similar situation where there was engagement with the private possessor of the disputed art, they were able to come to a compromise.

Interestingly, because they recognized that they were not able to establish ownership fully, the compromise was seen to be 'fair and just.' 90 This suggests that fairness and justice for claimants may also involve a normative consideration: where the claimants can establish ownership, they believe they are entitled to the return of their property; where they cannot establish ownership, compromise would be acceptable.

Additionally, the claim is laden with emotion for the family. For these claimants, the injustice lies not only in the fact that the art was taken from their family, but that the connection to the art is lost. To them it is 'very distressing' that their family's connection to a particular object is 'erased'.91 "We are not so concerned about restitution or financial redress, but about restoration of rights, rehabilitation and keeping alive the memory of Samuel van den Bergh."92 These are, arguably,

\footnotetext{
88 Campfens 2015, 143.

${ }^{89}$ Andriess and Sturm had claims also against private parties. There is a claim they have for a Steen painting, for which they feel certain they can fully establish ownership, yet the current owners of the artwork refuse to communicate with them. See Campfens 2015, 146, 148.

90 Campfens 2015, 146.

91 Campfens 2015, 148.

92 Campfens 2015, 148.
} 
Debbie De Girolamo - Revised Submission for the IJCP

August 30, 2019

sentiments of reconciliation rather than of enforcement of moral rights, which adds further complexity to these claims.

(c) Bas van Lier 93

This involved a claim for the return of eight ethnographic artifacts. The claimant had little hope for their restitution, and in fact the Committee denied the claim except for the return of one ivory horn. The Committee deemed their sale in 1941 valid with the exception of the ivory horn. Van Lier was satisfied with the outcome. The fact that the claim was investigated fully by 'an independent party' was important to van Lier. ${ }^{94}$ He felt that everything that could be done was done and he had confidence in the process. ${ }^{95}$ He says: "In some cases, though, it is not so much about restitution or compensation, but the way in which these cases are tackled."96

Being heard, being acknowledged, and being investigated by an outsider were relevant to van Lier's experience with restitution. This is juxtaposed to his view regarding another claim he made for an object that the Committee could not locate:

he felt that there should have been more investigation into this missing object by the Committee to ascertain what happened to the object. ${ }^{97}$ This emphasises the underlying need for claims to be seriously, carefully and fully investigated.

(II) The Claimant Narrative: procedural justice and reconciliation concerns

The focus for these claimants seems to be on the process they experienced in pursuit of their claims. It appears their concerns fall either within a procedural justice framework or one of reconciliation.

\footnotetext{
93 Campfens 2015, 223-230.

${ }^{94}$ Campfens 2015, 225.

95 Campfens 2015, 225-226.

96 Campfens 2015, 227.

97 Campfens 2015, 227.
} 
Debbie De Girolamo - Revised Submission for the IJCP

August 30, 2019

With regard to procedural justice, Tyler has explored its relevance to parties in dispute in the context of outcomes reached. He found that where parties were satisfied with the process leading to the outcome, they were satisfied with the outcome, no matter what the outcome. ${ }^{98}$ The process however requires that certain elements be present in the process: there must be an opportunity by parties to tell their story and to control its telling, a consideration of their story in a fair manner, and parties are to be treated with dignity and respect. ${ }^{99}$ Sevier, more particularly, describes the elements of procedural justice as it relates to party perception of fairness to include reference to the decision-maker's neutrality, respect towards the parties, party voice and autonomy, and trust in the decision-maker's fair treatment of the parties. ${ }^{100}$ Procedural justice, therefore, involves concepts of fair and equal treatment, equal access to the process, and the opportunity to be heard. Echoes of procedural justice elements can be heard in the claimants desire and need to be heard and acknowledged; for their claim to be considered by an objective, independent party; for their loss to be valued and acknowledged; and for the claim to be investigated thoroughly and carefully.

The concept of reconciliation is also suggested by these claimant narratives. A process of reconciliation would invoke elements of acknowledgment, validation and atonement. 101 The Truth and Reconciliation Commission of Canada had occasion to define reconciliation in the context of its findings on the Indigenous residential schools experience: "reconciliation is about establishing and maintaining a mutually respectful relationship between Aboriginal and non-Aboriginal peoples in this country. For that to happen, there has to be awareness of the past, acknowledgement of the harm that has been inflicted, atonement for the causes, and

\footnotetext{
98 Tyler 1988.

${ }^{99}$ Hollander-Blumoff 2017.

100 Sevier 2014, 212, 213.

101 The Final Report of the Truth \& Reconciliation Commission of Canada, Canada's Residential Schools: Reconciliation, Volume 6 (2015, McGill-Queen's University Press, Montreal \& Kingston). The Report is found at < http://www.trc.ca/assets/pdf/Volume_6_Reconciliation_English_Web.pdf>
} 
Debbie De Girolamo - Revised Submission for the IJCP

August 30, 2019

action to change behaviour."102 For the cultural property dispute, the relationship between victim and possessor must be respected as required by each of the parties and that respect must be nurtured through the process of resolution.

Acknowledgement of their claims seems to be an important consideration, as well as a need to make them whole again.

This sense of reconciliation suggested by these interviews is more clearly illustrated in the story of the Heinemann restitution of objects by Museum Luneburg in Germany, in which the claimants speak of healing and reconciliation through the act of restitution: "Little did I know that their act and words of apology would mean so much and our loan would be so transformative....renewal in a moment of restitution and reconciliation...it was a time of healing."103 The Heinemann descendants had been contacted by the Museum Luneburg about objects it held belonging to Marcus Heinemann. The act of restitution brought along with it an apology from the museum, reintegration into a community that had abandoned the family, and an opportunity for a family to come to terms with a tragic past. ${ }^{104}$ Veraart speaks to reconciliation as one of three possible paradigms from which to seek the fair and just solution. ${ }^{105}$ He sees it as a flexible, future-oriented approach that would encourage creative solutions and would sit within a legal framework of due process. 106 Perhaps, then it is not a question of morality, but more a question of process, whether that is a process that is said to be procedurally just or whether it is a process of reconciliation. Both are suggested by the claimant narrative.

\footnotetext{
102 The Final Report of the Truth \& Reconciliation Commission of Canada, Canada's Residential Schools: Reconciliation, Volume 6 (2015, McGill-Queen's University Press, Montreal \& Kingston) at 3. The Report is found at < http://www.trc.ca/assets/pdf/Volume_6_Reconciliation_English_Web.pdf> 103 Film produced and directed by Dr Becki Cohn- Vargas, Almost Lost: The Heinemann Legacy (2016) at < http://beckicohnvargas.com/the-heinemann-legacy>

104 For the Heinemann descendants, it was an opportunity to come together as a family, to learn about their family history, to share stories, to have their loss acknowledged, and it was also an opportunity for them to also acknowledge the Museum's actions by loaning the restituted objects back to the Museum; see Film produced and directed by Dr Becki Cohn- Vargas, Almost Lost: The Heinemann Legacy (2016) at < http://beckicohnvargas.com/the-heinemann-legacy> 105 For a discussion about the role of reconciliation, see Veraart 2015, 218-221.

106 Veraart 2015, 221.
} 
Debbie De Girolamo - Revised Submission for the IJCP

August 30, 2019

There has been much toing and froing as to what is the best process for disputes dealing with cultural property: the only seemingly clear consensus is the recognition that litigation is not always the best way to deal with such disputes. ${ }^{107}$ Morality has somehow stepped into the breach and is relied upon to support restitution claims, yet for these claimants, it is the process by which the claims were handled which led to what they considered to be fair and just solutions. It is to process and the processual needs of claimants that need to be the focus of inquiry. For these claimants, it is not about who is morally entitled to these art objects. It is more about the manner in which the decision on the claim is made: that their loss is acknowledged, their voice is heard with dignity and respect, and their efforts are validated. Morality as used in the field for the determination of Nazi looted art claims seems to be concerned with outcome: the moral claim is the fair and just claim. Process is considered only in so far as it becomes a vehicle for the application of morality to the issue of entitlement. A redirection to a processual focus is required to move away from the idea of a moral outcome. Process and morality are distinct notions: processual concepts of reconciliation and procedural justice do not rely on morality for their delivery.

\section{Conclusion}

The problem with morality as a moniker for the fair and just solution lies primarily with the identity of the arbiter of morality and the underlying values ascribed to it: whose community values will represent the valid and better moral claim; why should one moral claim override another; and why has morality, with its ephemeral ties to justice, become a defining feature of a fair and just solution for cultural property disputes? Are moral claims the real impetus for the return of cultural property or is morality representative of the recognition of a valid legal claim, but

\footnotetext{
${ }^{107}$ A contrary view is held by Veraart who argues that reconciliation processes require the assistance of the law and legal framework; see Veraart 2015. Campfens also sees the necessity of a legal framework: Campfens 2014, 88-89.
} 
Debbie De Girolamo - Revised Submission for the IJCP

August 30, 2019

one which is free of legal obstructionism permitted by legal rules and norms. ${ }^{108}$ In other words, morality may be about interests unobstructed by legal trappings such as limitation periods, documentary proof or forum conveniens issues, or it may be about rectifying past wrongs. Such purposes are laudable, but weaknesses of the approach need to be acknowledged.

This article presents an important contribution to the field for its detailed exposition about the role morality plays and should play in the determination of restitution claims. Its focus specifically on the problematic use of morality for these claims highlights the extent to which the field is relying on an amorphous, fluid concept to determine complex claims in a manner that lacks definitional boundaries and sits outside a justice framework. As such, morality should not be a basis on which entitlement is determined.

Another significant contribution is made by its argument that concepts of reconciliation and procedural justice appear to matter more for claimants in achieving a fair and just solution than a recognition of moral entitlement, requiring a re-assessment of the processual frame within which these claims are considered. Some in the field talk about a need for an international court or an international arbitration panel to assess and determine these claims, or at minimum, international co-operation. ${ }^{109}$ These suggestions are interesting, but premature. The issue of achieving a fair and just solution to Nazi looted art claims should also focus on what the claimants need from the process: rather than selecting a process that continues to be normative in context and focused on outcome, regard should be had to the claimant narrative and their processual needs surrounding the fair and just solution. From this, consideration can begin on the elements of an appropriate process to determine these claims.

\footnotetext{
108 O’Donnell 2011 says restitution's development lies in the establishment of a moral trend, however suggests that restitution is really about 'negotiated standards of justice' which supports the need for an appropriate justice framework argued here (51).

${ }^{109}$ See for example, Campfens 2015, 130-4; Kreder 2007, 157, 207, 216; and Renold and Chechi 2015, 199-200.
} 
Debbie De Girolamo - Revised Submission for the IJCP

August 30, 2019

As a result, a new dialogue regarding the relationship among the fair and just solution, morality and the broader justice framework is required to advance movement toward the attainment of the fair and just solution for these claims. This leads to the article's third notable contribution: it makes clear that a new conceptual framework is needed from which to assess the delivery of justice in these cases, one which is pluralistic to accommodate a consideration of different values and one that sits firmly within a justice framework. The claimant voice suggests a need to focus the dialogue on processual elements involving concepts of reconciliation and procedural justice, rather than on reliance of a nebulous and shape shifting concept of the moral claim. This would bring a new approach to the consideration of what is fair and just in the consensual resolution of claims dealing with Nazi looted art, and one that does not rely on the fickleness of moral superiority. 110

\section{BIBLIOGRAPHY}

Atkinson, Logan. 2002-2003. "The Birth of the Ought: Evolution, Moral Choice and the Hobbesian Myth." Ottawa Law Review 34: 307.

Bandle, Anne Laure and Theurich, Sarah. 2011. "Alternative Dispute Resolution and Art-Law - A New Research Project of the Geneva Art-Law Centre." Journal of International Communication Law and Technology 6(1): 28.

Berkowitz, Leonard and Walker, Nigel. 1967. "Law and Moral Judgments. Sociometry 30(4): 410.

Bowrey, Kathy. 2016. "Keeping their marbles: How the treasures of the past ended up in museums - and why they should stay there [Book Review]." Indigenous Law Bulletin 8(25): 20.

110 Warren 1999, in her examination of approaches to the resolution of cultural property issues, sees a need for a new conceptual framework from which to assess cultural property claims: essentially, she says that we need to move away from the dominant western adversarial mode of thinking about ownership involving a rights and rules framework to an integrative approach to resolution through a need to recognize various interests of the parties $(2,11-12$ and at 21-22 for discussion of an integrative framework). 
Debbie De Girolamo - Revised Submission for the IJCP

August 30, 2019

Burris, Donald S. 2016. "From Tragedy To Triumph In The Pursuit Of Looted Art: Altmann, Benningson, Portrait Of Wally, Von Saher And Their Progeny." The John Marshall Law School Review of Intellectual Property Law 15: 394.

Campfens, Evelien. 2014. “Alternative Dispute Resolution in Restitution Claims and the Binding Expert Opinion Procedure of the Dutch Restitutions Committee." In Art, Cultural Heritage and the Market: Ethical and Legal Issues, edited by Valentina Vadi and Hildegard E.G.S. Schneider, 61. London: Springer.

Campfens, Evelien (ed). 2015. Fair and just solutions: alternatives to litigation in Nazi-looted art disputes: status quo and new developments. The Hague: Eleven International Publishing.

Campfens, Evelien. 2017. "Nazi-Looted Art: A Note in Favour of Clear Standards and Neutral Procedures." Art Antiquity and Law XXII (4): 315.

Campfens, Evelien. 2019. “The Bangwa Queen: artifact or heritage?" International Journal of Cultural Property 26(1): 75.

Chechi, Alessandro. 2013. "Plurality and Coordination of Dispute Settlement Methods in the Field of Cultural Heritage." In Enforcing International Cultural Heritage Law, Francesco Francioni and James Gordley, 177. Oxford: Oxford University Press.

Chechi, Alessandro. 2014. The Settlement of International Cultural Heritage Disputes. Oxford: Oxford University Press.

Demarsin, Bert. 2010. "The Third Time is not always a Charm: The Troublesome Legacy of a Dutch Art Dealer: The Limitation and Act of State Defenses in Looted Art Cases." Cardozo Arts and Entertainment Law Journal 28: 255.

Demarsin, Bert. 2011. “Let's Not Talk About Terezín: Restitution Of Nazi Era Looted Art And The Tenuousness Of Public International Law." Brooklyn Journal of International Law 37: 117.

Dworkin, Ronald. 1997. Taking Rights Seriously. London: Duckworth.

Fincham, Derek. 2012. "Justice and the Cultural Heritage Movement: Using Environmental Justice to Appraise Art and Antiquities Disputes." Virginia Journal of Social Policy and the Law 20: 43.

Fincham, Derek. 2013a. “The Parthenon Sculptures and Cultural Justice.” Fordham Intellectual Property, Media and Entertainment Law Journal 23: 943.

Fincham, Derek. 2013b. "Social Norms and Illicit Cultural Heritage." In Enforcing International Cultural Heritage Law, edited by Francesco Francioni and James Gordley, 206. Oxford: Oxford University Press.

Finnis, John. 1980. Natural Law and Natural Rights. Oxford: Clarendon Press. 
Debbie De Girolamo - Revised Submission for the IJCP

August 30, 2019

Frankel, Simon J. and Forrest, Ethan. 2013. "Museums' Initiation Of Declaratory Judgment Actions And Assertion Of Statutes Of Limitations In Response To Nazi-Era Art Restitution Claims - A Defense." DePaul Journal of Art, Technology and Intellectual Property Law 23: 279.

Fuller, Lon. 1969. The Morality of Law, Second Edition. New Haven \& London: Yale University Press.

Gert, Bernard. 1999. “Morally Relevant Features.” Metaphilosophy 30(1/2): 13.

Gert, Bernard and Gert, Joshua. 2017. "The Definition of Morality.” In The Stanford Encyclopedia of Philosophy, edited by Edward N. Zalta.

Glendon, Mary Ann. 1991. Rights Talk: The Impoverishment of Political Discourse. Toronto: Collier Macmillan.

Gonthier, Charles D. The Honourable. 2003. "Law and Morality." Queen's Law Journal 29: 408.

Graefe, Emily A. 2010. "The Conflicting Obligations of Museums Possessing NaziLooted Art." Boston College Law Review 51: 473.

Green, Leslie. 2013. "Should Law Improve Morality?" Criminal Law and Philosophy 7: 473.

Hart, H.L.A. 1997. The Concept of Law. Oxford: Clarendon Press.

Hollander-Blumoff, Rebecca. 2017. "Formation of Procedural Justice Judgments in Legal Negotiations." Group Decision and Negotiation 26: 19.

Jenkins, Tiffany. 2016. Keeping Their Marbles: How the Treasures of the Past Ended up in Museums - And Why They Should Stay There. Oxford: Oxford University Press.

Kedar, Ronit Donyets. 2011. "The Unrecognized Dominance of Law in Morality: The Case of Promises." 24 Canadian Journal of Law and Jurisprudence. 24: 79.

Kreder, Jennifer Anglim. 2007. "Reconciling Individual And Group Justice With The Need For Repose In Nazi-Looted Art Disputes: Creation Of An International Tribunal." Brooklyn Law Review 73: 155.

Kreder, Jennifer Anglim. 2008. "The Holocaust, Museum Ethics and Legalism.” Southern California Review of Law and Social Justice 18(1): 1.

Kreder, Jennifer Anglim. 2009. “The New Battleground of Museum Ethics and Holocaust-Era Claims: Technicalities Trumping Justice or Responsible Stewardship for the Public Trust?" Oregon Law Review 88: 37.

Kreder, Jennifer Anglim. 2011. "Guarding the Historical Record from the Nazi-Era Art Litigation Tumbling toward the Supreme Court." University of Pennsylvania Law Review 159: 253. 
Debbie De Girolamo - Revised Submission for the IJCP

August 30, 2019

Kreder, Jennifer Anglim. 2016. “The 'Public Trust."” University of Pennsylvania Journal of Constitutional Law 18: 1425.

Markowitz, Sam. 2012. "A Meteorite and a Lost City: Mutually Beneficial Solutions Through Alternative Dispute Resolution." Cardozo Journal of Conflict Resolution 14: 219.

Merryman, John H. 1985. "Thinking about the Elgin Marbles." Michigan Law Review 83 (8): 1881.

Merryman, John H. 1986. "Two Ways of Thinking about Cultural Property.” The American Journal of International Law 80: 831.

Merryman, John H. 1989. “The Public Interest in Cultural Property.” California Law Review 77: 339.

Merryman, John H. 1998. "Cultural Property Ethics.” International Journal of Cultural Property 7(1): 21.

Merryman, John H. 2005. "Cultural Property Internationalism.” International Journal of Cultural Property 12: 11.

Messer, Kirsten. 2008. "Two Sides of the Same Coin: The Memory of the Holocaust at War with a Survivor." Northern Kentucky Law Review 35: 19.

Moser, Stephanie. 2017. "Keeping their marbles: How the treasures of the past ended up in museums - and why they should stay there [Book Review]" Journal of the History of Collections 29(3): 528.

Mullery, Jessica. 2010. "Fulfilling The Washington Principles: A Proposal For Arbitration Panels to Resolve Holocaust-Era Art Claims." Cardozo Journal of Conflict Resolution 11: 643.

Nielsen, L.B., Patel, N.A., and Rosner, J. 2017. "'Ahead of the Lawmen'”: Law and Morality in Disney Animated Films 1960-1998." Law, Culture and the Humanities 13(1): 104.

Nudelman, Maria. 2015. "Who Owns the Scythian Gold? The Legal and Moral Implications of Ukraine and Crimea's Cultural Dispute." Fordham International Law Journal 38: 1262.

O'Connell, Mary Ellen. 2008. "Beyond Wealth: Stories of Art, War, and Greed." Alabama Law Review 59: 1075.

O’Donnell, Thérèse. 2011. "The Restitution of Holocaust Looted Art and Transitional Justice: The Perfect Storm or the Raft of the Medusa?" European Journal of International Law 22(1): 49.

O'Manique, John. 2003. The Origins of Justice: The Evolution of Morality, Human Rights, and Law. Philadelphia: University of Pennsylvania Press. 
Debbie De Girolamo - Revised Submission for the IJCP

August 30, 2019

Oost, Tabitha I. 2012. In an Effort to do Justice? Restitution Policies and the Washington Principles. Amsterdam: Centre of Art, Law and Policy.

Oost, Tabitha I. 2018. "Restitution policies on Nazi-looted art in the Netherlands and the United Kingdom: A change from a legal to a moral paradigm?" International Journal of Cultural Property 25(2): 139.

Palmer, Norman. 2001. "Repatriation and Deaccessioning of Cultural Property: Reflections on the Resolution of Art Disputes." Current Legal Problems 54(1): 477.

Palmer, Norman. 2015. "The Best We Can Do? - Exploring a Collegiate Approach to Holocaust-related Claims." In Fair and just solutions? Alternatives to litigation in Nazi-looted art disputes: status quo and new developments, edited by Evelien Campfens, 153. The Hague: Eleven International Publishing.

Pauer-Studer, Herlinde. 2012. "Law and Morality under Evil Conditions: The SS Judge Konrad Morgen." Jurisprudence 3(2): 367.

Perry, Michael J. 2000. “What is Morality Anyway?” Villanova Law Review 45(1): 69.

Plachta, Michael. 2019. "European Parliament Adopts Resolution on Cross-Border Restitution Claims of Works of Art and Cultural Goods." International Enforcement Law Reporter 35(1): 11.

Rawls, John. 1971. A Theory of Justice. Cambridge, Mass.: Belknap Press of Harvard University.

Renold, Marc-Andre. 2015. "Cultural Co-ownership: Preventing and Solving Cultural Property Claims." 22(2/3) International Journal of Cultural Property 22(2/3): 163.

Renold, Marc-Andre and Chechi, Alessandro. 2015. "Just and Fair Solutions: An Analysis of International Practice and Trends." In Fair and just solutions?

Alternatives to litigation in Nazi-looted art disputes: status quo and new developments, edited by Evelien Campfens, 187. The Hague: Eleven International Publishing.

Reppas , Michael J. 2007. “Empty 'International’ Museums' Trophy Cases of Their Looted Treasures and Return Stolen Property to the Countries of Origin and the Rightful Heirs of Those Wrongfully Dispossessed." Denver Journal of International Law and Policy 36: 93.

Reyhan, Patricia Y. 2001. "A Chaotic Palette: Conflict of Laws in Litigation Between Original Owners and Good-faith Purchasers of Stolen Art." Duke Law Journal 50: 955.

Roodt, Christa. 2013. "State Courts or ADR in Nazi-era Art Disputes: A Choice 'More Apparent than Real'?" Cardozo Journal of Conflict Resolution 14: 421.

Sandel, Michael J. 1982. Liberalism and the Limits of Justice. Cambridge: Cambridge University Press. 
Debbie De Girolamo - Revised Submission for the IJCP

August 30, 2019

Seligman, Thomas K. 1999. "The Murals of Teotihuacan: A Case Study of Negotiated Restitution." In The Ethics of Collecting Cultural Property: Whose Culture? Whose Property?, edited by Phyllis Mauch Messenger, 73. Albuquerque: University of New Mexico Press.

Sevier, Justin. 2014. "The Truth-Justice Tradeoff: Perceptions of Decisional Accuracy and Procedural Justice in Adversarial and Inquisitorial Legal Systems." Psychology, Public Policy and Law 20: 212

Shyllon, F. 2015. "Restitution of Antiquities to Sub-Saharan Africa: The Booty and Captivity: A study of some of the unsuccessful efforts to retrieve cultural objects purloined in the age of imperialism in Africa." Art Antiquity and Law 20(4): 369.

Skinner, Katharine N. 2013. "Restituting Nazi-Looted Art: Domestic, Legislative, and Binding Intervention to Balance the Interests of Victims and Museums." Vanderbilt Journal of Entertainment and Technology Law 15: 673.

Soltes, Ori Z. 2016. "Cultural Plunder and Restitution and Human Identity." The John Marshall Law School Review of Intellectual Property Law 15: 460.

Thompson, Erin L. 2011. "Cultural Losses and Cultural Gains: Ethical Dilemmas in WWII-Looted Art Repatriation Claims Against Public Institutions." Hastings Communications \& Entertainment Law Journal 33: 407.

Tyler, Tom R. 1988. "What Is Procedural Justice - Criteria Used by Citizens to Assess the Fairness of Legal Procedures." Law and Society Review 22: 103.

Veraart, Wouter. 2015. "Between Justice and Legal Closure: Looted Art Claims and the Passage of Time." In Fair and just solutions? Alternatives to litigation in Nazilooted art disputes: status quo and new developments, edited by Evelien Campfens, 211. The Hague: Eleven International Publishing.

Walzer, Michael. 1983. Spheres of Justice: A Defense of Pluralism and Equality. New York: Basic Books, Inc.

Warren, Karen J. 1999. "A Philosophical Perspective on the Ethics and Resolution of Cultural Properties Issues." In The Ethics of Collecting Cultural Property: Whose Culture? Whose Property?, edited by Phyllis Mauch Messenger, 1. Albuquerque: University of New Mexico Press.

Weller, Matthias. 2015. "Key Elements of Just and Fair Solutions - The Case for a Restatement of Restitution Principles." In Fair and just solutions? Alternatives to litigation in Nazi-looted art disputes: status quo and new developments, edited by Evelien Campfens, 201. The Hague: Eleven International Publishing.

Woodhead, Charlotte. 2014. "Redressing Historic Wrongs, Returning Objects to their Rightful Owners or Laundering Tainted Objects? 21st-Century UK Remedies for Nazi-era Injustices." International Journal of Cultural Property 21(2): 113. 
Debbie De Girolamo - Revised Submission for the IJCP August 30, 2019

Woodhead, Charlotte. 2015. "The Changing Tide of Title to Cultural Heritage Objects in UK Museums." International Journal of Cultural Property 22(2/3): 229.

Woodhead, Charlotte. 2016. "Putting in Place Solutions for Nazi Era Dispossessions of Cultural Objects: the UK experience." International Journal of Cultural Property 23(4): 385. 